\title{
Disabilitas Klien Pasca Stroke terhadap Depresi
}

\author{
Maria Magdalena Purba ${ }^{1}$, Nang Randu Utama ${ }^{2}$ \\ Jurusan Keperawatan, Poltekkes Kemenkes Palangka Raya, Indonesia \\ Email: mariapurba45@gmail.com
}

\begin{abstract}
Post Stroke Client Disability to Depression. Stroke is one of the public health problems in the world. Stroke can cause disability and functional disorders. The incidence of stroke in Indonesia increased sharply to become the third leading cause of death after heart disease and cancer. This study aims to determine the level of disability of clients after stroke against depression. Observational analytic research design with a cross-sectional design, performed at dr. Doris Sylvanus Palangka Raya in the Neural Poly Room. The Barthel index instrument to measure the level of disability, and the Hamilton scale instrument (HDRS) to measure the level of depression. The population in this study were post-stroke clients with disabilities who went out to the neurology clinic of dr. Doris Sylvanus Palangka Raya Hospital in the period January-June 2017 as many as 58 clients after stroke, so that by using the Sugiyono formula the sample size in this study was 38 people. The results of the study showed a significant relationship between the age of the patients after stroke with the level of depression with a value of $p$-value $=0,032$ and with a level of disability with a value of $p$-value $=0,006$ ( $p$-value $<0,05), p$-value $=0,000$ ( $p$-value $<0,05$ ). The results of the analysis of the level of disability of patients after stroke against depression are shown with a value of $\mathrm{p}$-value $=0,018$ ( $\mathrm{p}$-value $<0,05$ ). There is a significant relationship between the level of disability of patients post-stroke for depression. Health education is needed to improve disability and depression in post-stroke patients.
\end{abstract}

Keywords: Depression, Level of disability, Post-stroke, Stroke

\begin{abstract}
Abstrak: Disabilitas Klien Pasca Stroke terhadap Depresi. Stroke merupakan salah satu masalah kesehatan masyarakat di dunia. Stroke dapat menyebabkan disabilitas dan gangguan fungsional. Angka kejadian stroke di Indonesia meningkat tajam menjadi urutan ketiga penyebab kematian setelah penyakit jantung dan kanker. Penelitian ini bertujuan untuk mengetahui tingkat disabilitas klien pasca stroke terhadap depresi. Desain penelitian analitik observasional dengan rancangan cross-sectional, dilaskanakan di RSUD dr. Doris Sylvanus Palangka Raya di ruang Poli Syaraf. Instrument indeks Barthel untuk mengukur tingkat disabilitas, dan instrumen skala Hamilton (HDRS) untuk mengukur tingkat depresi. Populasi dalam penelitian ini adalah klien pasca stroke dengan disabilitas yang berobat jalan ke poli Syaraf RSUD dr Doris Sylvanus Palangka Raya periode Januari-Juni 2017 sebanyak 58 klien pasca stroke, sehingga dengan menggunakan rumus Sugiyono besar sampel dalam penelitian ini adalah 38 orang. Hasil penelitian ada hubungan yang segnifikan antara umur pasien pasca stroke dengan tingkat depresi dengan nilai $p$-value $=0,032$ dan dengan tingkat disabilitas dengan nilai $p$-value $=0,006$ ( $p$-value $<0,05)$, hubungan karakterisitik tingkat disabilitas pasien pasca sroke berdasasarkan status perkawinan menunjukan hasil yang signifikan dengan nilai $p$-value $=0,000$ ( $p$-value $<0,05)$. Hasil analisis tingkat disabilitas pasien pasca stroke terhadap depresi ditunjukkan dengan nilai $p$-value $=0.018$ ( $p$-value $<0,05)$. Ada hubungan yang bermakna antara tingkat disabilitas pasien pasca stroke terhadap depresi. Perlu adanya peningkatana edukasi kesehatan untuk mengatasi disabilitas dan depresi pada pasien pasca stroke.
\end{abstract}

Kata Kunci: Depresi, Tingkat disabilitas, Pasca stroke, Stroke

\section{PENDAHULUAN}

Stroke merupakan salah satu masalah kesehatan masyarakat didunia. Stroke dapat menyebabkan disabilitas dan gangguan fungsional. Stroke merupakan salah satu syndrome neurologi yang dapat menimbulkan kecacatan dalam kehidupan manusia (Tantular, 2015).

Data menunjukkan setiap tahunnya stroke menyerang sekitar 15 juta orang di seluruh dunia. Di Amerika Serikat, lebih kurang lima juta orang pernah mengalami stroke. Sementara di Inggris, tercatat 250 ribu orang hidup dengan kecatatan 
karena stroke. Stroke, sebagai salah satu penyebab morbiditas dan mortalitas, menunjukkan angka kecenderungan yang semakin meningkat dari tahun ketahun. Stroke menjadi penyebab kematian terbanyak dan disabilitas yang lama di seluruh dunia. World Health Organizitaion (WHO) menetapkan bahwa stroke merupakan suatu sindrom klinis yang ditandai dengan gejala berupa gangguan fungsi otak, yang dapat menimbulkan kematian atau kelainan yang menetap lebih dari 24 jam, yang dapat berupa kecacatan fisik dan hilangnya fungsi fisik seperti kelumpuhan dan gangguan komunikasi (Rahayu, 2014). Stroke juga merupakan salah satu kegawatan neurologik yang dianggap sebagai masalah besar yang tengah dihadapi seluruh dunia.

WHO memprediksi bahwa kematian akibat stroke akan meningkat seiring dengan kematian akibat penyakit jantung dan kanker kurang lebih 6 juta pada tahun 2010 menjadi 8 juta di tahun 2030 (American Heart Association, 2010). Menurut Yayasan Stroke Indonesia (YASTROKI) (2012), jumlah penderita stroke di Indonesia terbanyak dan menduduki urutan pertama di Asia. Stroke juga merupakan penyebab kecacatan serius menetap nomor 1 di seluruh dunia.

Angka kejadian stroke di Indonesia meningkat tajam menjadi urutan ketiga penyebab kematian setelah penyakit jantung dan kanker. Angka kejadian, stroke di Indonesia tertinggi dibandingkan negara-negara lain yang memiliki resiko sama dengan di Indonesia. Hasil Data Riskesdas pada tahun 2013 dikemukakan bahwa 7 dari 1000 orang di Indonesia terkena stroke, data tersebut menunjukkan bahwa stroke merupakan penyebab kematian utama pada semua umur dengan proporsi stroke $(15,4 \%)$. Prevalensi Stroke berdasarkan hasil diagnosis dan gejalanya diperoleh data tertinggi adalah di Sulawesi Selatan yaitu $(17,9 \%$ ), DI Yogyakarta $(16,9 \%$ ), Sulawesi Tengah $(16,6 \%$ ), diikuti Jawa Timur sebesar (16,9\%), Sedangkan di Kalimantan tengah berjumlah 12,1\%o), Data hasil Rekam Medik RSUD dr. Doris Sylvanus Palangka Raya, menunjukkan bahwa jumlah klien stroke yang dirawat inap mengalami peningkatan setiap tahunnya. Pada tahun 2010 tercatat 297 orang klien stroke, tahun 2011 tercatat 426 orang klien stroke, pada tahun 2012 meningkat lagi menjadi 467 orang, tahun 2013 klien stroke yang dirawat inap juga mengalami peningkatan yaitu sebanyak 478 orang, sedangkan pada tahun 2014 klien stroke mengalami angka penurunan yaitu tercatat sebanyak 433 klien. Sedangkan untuk periode tahun 2016 jumlah penderita tercatat sejumlah
497 dan tahun 2017 periode antara bulan Oktober sampai bulan Desember jumlah klien stroke yang di rawat inap di ruang Neorologi RSUD dr. Doris Sylvanus Palangka Raya berjumlah 155 kasus dengan stroke. Data ini menunjukan bahwa angka klien stroke yang dirawat di ruang rawat inap neorologi RSUD dr.Doris Sylvanus masih tinggi sehingga perlu perhatian yang serius. Perhatian yang serius terutama ditujukan tehadap kondisi disabilitas yang terjadi akibat gejala sisa pada klien pasca stroke.

Disabilitas pada klien pasca stroke dapat berupa penurunan fungsi ektermitas, seperti adanya hemiparise pada ekstermitas. Gangguan fungsi ekstremitas atas merupakan masalah umum yang sangat membebani klien pasca stroke. Gangguan ekstermitas klien pasca stroke ini lah yang menyebabkan disabilitas pada klien pasca stroke. Hal ini sependapat dengan apa yang dikemukakan Avicenna, (2010) yang menyatakan bahwa 56\% klien masih menunjukkan hemiparesis yang nyata setelah diperiksa lima tahun pasca serangan stroke, hemiparise yang dialami oleh klien dengan pasca stroke ini lah yang menyebabkan klien pasca stroke mengalami disabilitas sehingga dalam melakukan aktivitas atau kegiatanya sehari-hari tergantung dengan orang lain. Dimana sebelumnya klien mampu melakukan aktivitas sehari-hari tanpa bantuan orang lain. Hal inilah yang menjadi dampak psikologis pada klien pasca stroke, yang berpengaruh terhadap gangguan status mental/kognitif dan bahkan sampai depresi serta gangguan bahasa.

Dampak psikologis yang terjadi pada klien pasca stroke dapat berupa kecemasan, perubahan konsep diri sampai kepada depresi. Depresi merupakan gangguan neuropsikiatri yang paling banyak terjadi pada klien pasca stroke. Sekitar 35\% klien pasca storke mengalami depresi. Depresi Pasca Stroke (DPS) ditandai oleh perasaan sedih, hilangnya minat terhadap aktivitas dan berkurangnya energi. Biantoro dkk, (2015). Depresi pasca-stroke merupakan salah satu komplikasi stroke yang ditandai oleh abnormalitas mood, menyalahkan diri sendiri, kesedihan bahkan sampai depresi. Susilawaty (2014) mengemukakan bahwa depresi pasca stroke merupakan faktor utama yang dapat menghambat penyembuhan fungsi neurologi dan aktivitas harian pada klien stroke dan peningkatan mortalitas. Sehingga kontribusi perawat sebagai tenaga kesehatan yang berperan dalam memberikan asuhan keperawatan pada klien pasca stroke dapat mengurangi terjadinya depersi pada klien pasca stroke. Tujuan penelitian 
mengetahui tingkat disabilitas klien pasca stroke terhadap depresi.

\section{METODE}

Penelitian ini merupakan penelitian kuantitatif menggunakan desain penelitian analitik observasional dengan rancangan crosssectional. Populasi dalam penelitian ini adalah klien pasca stroke dengan disabilitas yang berobat jalan ke poli syaraf RSUD dr Doris Syvanus Palangka Raya. Pengambilan sampel menggunakan purposive sampling dengan jumlah sampel ditetapkan berdasarkan kriteria inklusi yaitu klien dengan disabilitas pasca stroke yang rawat jalan di poli syaraf RSUD dr Doris Sylvanus Palangka Raya periode Januari-Juni 2017 sebanyak 58 klien pasca stroke, sehingga dengan menggunakan rumus Sugiyono, (2010) besar sampel penelitan adalah 38 orang

Penelitian ini dilaksanakan diruang poli syaraf dan Unit Rehabilitasi RSUD dr Doris Sylvanus Palangka Raya pada bulan JuliOktober 2018. Pengukuran tingkat disabilitas menggunakan instrument indeks Barthel, yang sudah dipakai secara luas dan telah di uji reabilitasanya dengan $\mathrm{r}=0.73$, sedangkankan untuk tingkat depresi menggunakan instrumen menurut skala Hamilton (HDRS) yang sudah baku yang telah di uji reabilitasnya, dengan nilai $r$ hitung $>r$ nilai korealasi sebesar $r=0.68$.

Analisis data dilakukan melalui analisis univariat untuk karakateristik responden yang meliputi jenis kelamin, kelompok Umur, Stastus Perkawianan serta pendidikan jenis Kelamin. Analisis bivariat dilakukan untuk memperoleh gambaran hubungan antara karakteristik klien pasca stroke berdasarkan tingkat depresi dan tingkat disabilitas dengan menggunakan uji Chi Square.

\section{HASIL}

Tabel 1. Distribusi frekuensi Karakteristik responden

\begin{tabular}{lrr}
\hline Karakteristik & n & \multicolumn{1}{c}{$\%$} \\
\hline Jenis Kelamin & & \\
Laki-laki & 21 & 55,3 \\
Perempuan & 17 & 44,7 \\
\hline Kelompok Umur & & \\
\hline$\leq 40$ & 2 & 5,3 \\
$41-50$ & 3 & 7,9 \\
$51-60$ & 18 & 47,4 \\
$61-70$ & 10 & 26,3 \\
$>70$ & 5 & 13,2 \\
\hline Status Perkawinan & & \\
\hline Kawin & 32 & 84,2 \\
Belum Kawin & 1 & 2,6 \\
Duda / Janda & 5 & 13,2 \\
\hline Pendidikan & & \\
\hline SD & 5 & 13,2 \\
SMP & 3 & 7,9 \\
SMA & 19 & 50,0 \\
Perguruan Tinggi & 11 & 28,9 \\
\hline Pekerjaan & & \\
\hline PNS / TNI / POLRI & 20 & 52,6 \\
Wiraswasta & 8 & 21,1 \\
Petani & 4 & 10,5 \\
Tidak bekerja & 6 & 15,8 \\
\hline Total & $\mathbf{3 8}$ & $\mathbf{1 0 0 , 0}$ \\
\hline
\end{tabular}

Berdasarkan tabel 1 karakteristik respoden berdasarkan jenis kelamin yaitu laki-laki sebanyak 21 orang atau sebesar 55,3\% dan perempuan sebanyak 17 orang atau sebesar $44,7 \%$, sedangkan berdasarkan kelompok umur usia yang tertinggi adalah kelompok umur 51-60 tahun yaitu sebanyak 18 orang sebesar $47,4 \%$ dan yang terendah adalah usia $\leq 40$ tahun sebanyak 2 orang atau sebesar 5,3\%. Untuk status perkawinan dari tabel tersebut yang terbanyak adalah status menikah yaitu sebanyak 32 orang atau sebesar $84,2 \%$ dan yang terendah adalah belum menikah yaitu sebanyak 1 orang atau sebesar 2,6\%. Berdasarkan tingkat pendidikan responden terbanyak adalah berpendidikan SLTA yaitu sebanyak 19 orang atau sebesar 50\% dan yang terendah adalah tingkat pendidikan SMP sebanyak 3 orang atau sebesar 7,9\%, bila dianalisis berdasarkana pekerjaan maka respoden yang tertinggi adalah pekerjaan PNS, TNI dan Polri sebanyak 20 respoden atau sebesar 52,6\% dan yang terendah adalah tidak bekerja dengan jumlah responden sebanyak 6 orang atau sebesar $15,8 \%$. 
Tabel 2. Hubungan Karakteristik Tingkat Depresi Pasien Pasca Stroke

\begin{tabular}{|c|c|c|c|c|c|c|c|c|c|c|c|}
\hline \multirow{3}{*}{ Karakteristik } & \multicolumn{8}{|c|}{ Tingkat Depresi } & \multirow{2}{*}{\multicolumn{2}{|c|}{ Total }} & \multirow[t]{3}{*}{$\begin{array}{c}p- \\
\text { value }\end{array}$} \\
\hline & \multicolumn{2}{|c|}{ Normal } & \multicolumn{2}{|c|}{ Ringan } & \multicolumn{2}{|c|}{ Sedang } & \multicolumn{2}{|c|}{ Berat } & & & \\
\hline & $\mathbf{n}$ & $\%$ & $\mathbf{n}$ & $\%$ & $\mathbf{n}$ & $\%$ & $\mathbf{n}$ & $\%$ & $\mathbf{n}$ & $\%$ & \\
\hline \multicolumn{12}{|l|}{ Jenis Kelamin } \\
\hline Laki-laki & 3 & 14,3 & 3 & 4,3 & 4 & 23,8 & 10 & 47,6 & 21 & 100,0 & 0,396 \\
\hline Perempuan & 2 & 11,8 & 0 & 0,0 & 5 & 23,5 & 11 & 64,7 & 17 & 100,0 & \\
\hline \multicolumn{12}{|l|}{ Kelompok Umur } \\
\hline$\leq 40$ & 2 & 100,0 & 0 & 0,0 & 0 & 0,0 & 0 & 0,0 & 2 & 100,0 & 0,032 \\
\hline $41-50$ & 0 & 0,0 & 0 & 0,0 & 1 & 33,3 & 2 & 66,7 & 3 & 100,0 & \\
\hline $51-60$ & 2 & 11,1 & 1 & 5,6 & 3 & 16,7 & 12 & 66,7 & 18 & 100,0 & \\
\hline $61-70$ & 1 & 10,0 & 1 & 10,0 & 5 & 50,0 & 3 & 30,0 & 10 & 100,0 & \\
\hline$>70$ & 0 & 0,0 & 1 & 20,0 & 0 & 0,0 & 4 & 80,0 & 5 & 100,0 & \\
\hline \multicolumn{12}{|l|}{ Status perkawinan } \\
\hline Kawin & 4 & 12,5 & 3 & 9,4 & 7 & 21,9 & 18 & 56,3 & 32 & 100,0 & 0,211 \\
\hline Belum Kawin & 1 & 100,0 & 0 & 0,0 & 0 & 0,0 & 0 & 0,0 & 1 & 100,0 & \\
\hline Duda / Janda & 0 & 0,0 & 0 & 0,0 & 2 & 40,0 & 3 & 60,0 & 5 & 100,0 & \\
\hline \multicolumn{12}{|l|}{ Pendidikan } \\
\hline SD & 0 & 0,0 & 0 & 0,0 & 1 & 20,0 & 4 & 80,0 & 5 & 100,0 & 0,651 \\
\hline SMP & 0 & 0,0 & 0 & 0,0 & 0 & 0,0 & 3 & 100,0 & 3 & 100,0 & \\
\hline SMA & 2 & 10,5 & 2 & 10,5 & 5 & 26,3 & 10 & 52,5 & 19 & 100,0 & \\
\hline Perguruan Tinggi & 3 & 27,3 & 1 & 9,1 & 3 & 27,3 & 4 & 36,4 & 11 & 100,0 & \\
\hline \multicolumn{12}{|l|}{ Pekerjaan } \\
\hline PNS/ TNI/ POLRI & 4 & 20,0 & 2 & 10,0 & 5 & 25,0 & 0 & 45,0 & 20 & 100,0 & 0,847 \\
\hline Wiraswasta & 1 & 12,5 & 1 & 12,5 & 2 & 25,0 & 4 & 50,0 & 8 & 100,0 & \\
\hline Petani & 0 & 0,0 & 0 & 0,0 & 1 & 25,0 & 3 & 75,0 & 4 & 100,0 & \\
\hline Tidak Bekerja & 0 & 0,0 & 0 & 0,0 & 1 & 16,7 & 5 & 83,3 & 6 & 100,0 & \\
\hline
\end{tabular}

Tabel 3. Hubungan Karakteristik Pasien Pasca Stroke Berdasarkan Tingkat Disabilitas

\begin{tabular}{|c|c|c|c|c|c|c|c|c|c|c|c|}
\hline \multirow{3}{*}{ Karakteristik } & \multicolumn{8}{|c|}{ Tingkat Disabilitas } & & & \multirow{3}{*}{$\begin{array}{c}p- \\
\text { value }\end{array}$} \\
\hline & \multicolumn{2}{|c|}{ Mandiri } & \multicolumn{2}{|c|}{$\begin{array}{l}\text { Ketergan- } \\
\text { tungan } \\
\text { Ringan }\end{array}$} & \multicolumn{2}{|c|}{$\begin{array}{l}\text { Ketergan- } \\
\text { tungan } \\
\text { Sedang }\end{array}$} & \multicolumn{2}{|c|}{$\begin{array}{c}\text { Ketergan- } \\
\text { tungan } \\
\text { Berat }\end{array}$} & \multicolumn{2}{|c|}{ Total } & \\
\hline & $\mathbf{n}$ & $\%$ & $\mathbf{n}$ & $\%$ & $\mathbf{n}$ & $\%$ & $\mathbf{n}$ & $\%$ & $\mathbf{n}$ & $\%$ & \\
\hline \multicolumn{12}{|l|}{ Jenis Kelamin } \\
\hline Laki-laki & 4 & 19,0 & 1 & 4,8 & 5 & 23,8 & 11 & 52,4 & 21 & 100,0 & 0,768 \\
\hline Perempuan & 4 & 23,5 & 0 & 0,0 & 3 & 17,6 & 10 & 58,8 & 17 & 100,0 & \\
\hline \multicolumn{12}{|l|}{ Kelompok Umur } \\
\hline$\leq 40$ & 1 & 50,0 & & 50,0 & 0 & 0,0 & 0 & 0,0 & 2 & 100,0 & \\
\hline $41-50$ & 0 & 0,0 & 0 & 0,0 & 1 & 33,3 & 2 & 66,7 & 3 & 100,0 & 0,006 \\
\hline $51-60$ & 2 & 11,1 & 0 & 0,0 & 4 & 22,2 & 12 & 66,7 & 18 & 100,0 & \\
\hline $61-70$ & 2 & 20,0 & 0 & 0,0 & 3 & 30,0 & 5 & 50,0 & 10 & 100,0 & \\
\hline$>70$ & 3 & 60,0 & 0 & 0,0 & 0 & 0,0 & 2 & 40,0 & 5 & 100,0 & \\
\hline \multicolumn{12}{|l|}{ Status perkawinan } \\
\hline Kawin & 7 & 21,9 & 0 & 0,0 & 6 & 18,8 & 19 & 59,4 & 32 & 100,0 & 0,000 \\
\hline Belum Kawi & 0 & 0,0 & 1 & 100,0 & 0 & 0,0 & 0 & 0,0 & 1 & 100,0 & \\
\hline Duda / Janda & 1 & 20,0 & 0 & 0,0 & 2 & 40,0 & 2 & 40,0 & 5 & 100,0 & \\
\hline \multicolumn{12}{|l|}{ Pendidikan } \\
\hline SD & 0 & 0,0 & 0 & 0,0 & 0 & 0,0 & 5 & 100,0 & 5 & 100,0 & 0,308 \\
\hline SMP & 0 & 0,0 & 0 & 0,0 & 0 & 0,0 & 3 & 100,0 & 3 & 100,0 & \\
\hline SMA & 5 & 26,3 & 0 & 0,0 & 5 & 26,3 & 9 & 47,4 & 19 & 100,0 & \\
\hline Perguruan Tinggi & 3 & 27,3 & 1 & 9,1 & 3 & 27,3 & 4 & 36,4 & 11 & 100,0 & \\
\hline \multicolumn{12}{|l|}{ Pekerjaan } \\
\hline PNS/ TNI/ POLRI & 6 & 30,0 & 1 & 5,0 & 6 & 30,0 & 7 & 35,0 & 20 & 100,0 & 0,493 \\
\hline Wiraswasta & 1 & 12,5 & 0 & 0,0 & 1 & 12,5 & 6 & 75,0 & 8 & 100,0 & \\
\hline Petani & 0 & 0,0 & 0 & 0,0 & 0 & 0,0 & 4 & 100,0 & 4 & 100,0 & \\
\hline Tidak Bekerja & 1 & 16,7 & 0 & 0,0 & 1 & 16,7 & 4 & 66,7 & 6 & 100,0 & \\
\hline
\end{tabular}


Dari hasil analasis hubungan karakterisitik tingkat depresi pasien pasca sroke terhadap kelompok umur pada tabel 2 diperoleh hasil bahwa ada hubungan yang segnifikan antara umur pasien pasca stroke dengan tingkat depresi dengan nilai $p$-value $=0,032 \quad(p$-value $<0.05)$. Sedangkan hubungan karakterisitik tingkat depresi pasien pasca sroke terhadap jenis kelamin, status perkawinan, pendidikan dan pekerjaan tidak menunjukkan hasil yang bermakna yaitu ( $p$-value $>0,05)$.
Dari hasil analasis hubungan karakterisitik pasca sroke dengan tingkat disabilitas terhadap kelompok umur dan status perkawiana pada tabel 3 diperoleh hasil bahwa ada hubungan yang segnifikan antara umur dan status perkawinan pasien pasca stroke dengan tingkat disabilitas dimana nilai $p$-value $<0,05$, yaitu umur nilai $p$ value $=0,006$, dan status perkawinan nilai $p$ value $=0,000$.

Tabel 4. Hubungan Tingkat Disabilitas Pasien Pasca Stroke terhadap Depresi

\begin{tabular}{|c|c|c|c|c|c|c|c|c|c|c|c|}
\hline \multirow{3}{*}{ Tingkat Disabilitas } & \multicolumn{8}{|c|}{ Tingkat Depresi } & \multirow{2}{*}{\multicolumn{2}{|c|}{ Total }} & \multirow{3}{*}{ p-value } \\
\hline & \multicolumn{2}{|c|}{ Normal } & \multicolumn{2}{|c|}{ Ringan } & \multicolumn{2}{|c|}{ Sedang } & \multicolumn{2}{|c|}{ Berat } & & & \\
\hline & $\mathbf{n}$ & $\%$ & n & $\%$ & $\mathbf{n}$ & $\%$ & $\mathbf{n}$ & $\%$ & $\mathbf{n}$ & $\%$ & \\
\hline Mandiri & 3 & 37,5 & 1 & 12,5 & 1 & 12,5 & 3 & 37,5 & 8 & 100,0 & 0,018 \\
\hline Ketergantungan Ringan & 1 & 100,0 & 0 & 0,0 & 0 & 0,0 & 0 & 0,0 & 1 & 100,0 & \\
\hline Ketergantungan Sedang & 1 & 12,5 & 1 & 12,5 & 4 & 50,0 & 2 & 25,0 & 2 & 25,0 & \\
\hline Ketergantungan Berat & 0 & 0,0 & 1 & 4,8 & 4 & 19,0 & 16 & 76,2 & 21 & 100,0 & \\
\hline Total & 5 & 13,2 & 3 & 7,9 & 9 & 23,7 & 21 & 55,3 & 38 & 100,0 & \\
\hline
\end{tabular}

Pada tabel 4 analisis hubungan tingkat disabilitas pasien pasca stroke terhadap depresi . menunjukkan bahwa ada hubungan yang bermakna antara tingkat disabilitas pasien pasca stroke terhadap depresi, yang ditunjukkan dengan nilai $p$-value $=0,018$.

\section{PEMBAHASAN}

Hasil analisis univariat yang telah dilakukan oleh peneliti diperoleh hasil bahwa dari 38 responden pasien pasca stroke dengan disabilitas menunjukkan jenis kelamin laki-laki lebih banyak dari pada perempuan yaitu 21 orang atau sebesar $55,3 \%$ dan perempuan sebanyak 17 orang atau sebesar $44,7 \%$, sedangkan berdasarkan kelompok umur usia yang tertinggi adalah kelompok umur 51-60 tahun yaitu sebanyak 18 orang sebesar $47,4 \%$ dan yang terendah adalah usia $\leq 40$ tahun sebanyak 2 orang atau sebesar 5,3\%. Untuk status perkawinan dari table tersebut yang terbanyak adalah status menikah yaitu sebanyak 32 orang atau sebesar $84,2 \%$ dan yang terendah adalah belum menikah yaitu sebanyak 1 orang atau sebesar $2,6 \%$. jika dilaihat berdasarkan tingkat pendidikan responden terbanyak adalah berpendidikan SLTA yaitu sebanyak 19 orang atau sebesar 50\% dan yang terendah adalah tingkat pendidikan SMP sebanyak 3 orang atau sebesar 7,9\%, hasil analsis berdasarkana pekerjaan tertinggi adalah pekerjaan PNS/TNI/ Polri sebanyak 20 respoden atau sebesar $52,6 \%$ dan yang terendah adalah tidak bekerja/IRT dengan jumlah responden sebanyak 6 orang atau sebesar $15.8 \%$.
Hasil analisis hubungan karakteristik pasien pasca stroke berdasarkan tingkat disabilitas dianalisis melalaui analisis bivariate dengan uji cross sectional terhadap jenis kelamin, tingkat pendidikan dan pekerjaan, menunjukkan hasil analisis tidak bermakna dengan nilai $p$ value $>0,05$. Hasil analsis ini sependapat dengan penelitian Munir, et al (2016) yang mengemukan bahwa tidak ada hubungan jenis kelamin dengan depresi pasaca stroke. Sedangakan hasil analisis hubungan karakteristik tingkat disabilitas pasien pasca stroke terhadap kelompok umur menunjukkan hasil yang signifikan dengan nilai $p$-value $=0.006$ ( $p$-value $<0,05)$, hasil ini sesuai dengan penelitian Munir, et al (2016) yang mengemukan semakin tua penderita pasca stroke, semakin tinggi tingkat disabilitas yang dialami. Disabilitas yang dialami terjadi sebagai dampak dari penuruan fungsional dan kecenderungan mangalami masalah kesehatan yang menetap dan berpontensi untuk menimbulkan ketidakmampuan untuk melakukan kegiatan sehari-hari. Pasien pasca stroke dengan tingkat disabilitas yang tinggi tidak dapat hidup mandiri, sebagian besar aktivitas kehidupannya memerlukan bantuan dan tergantung dari orang lain yang merawatnya dan menimbulkan keterbatasan dan kehilangan kemampuan untuk melakukan kegiatan hibup sehari-hari. Dimana akhirnya ganggaun disabilitas akan membatasi pasien pasca stroke untuk melakukan aktivitasnya.

Hasil analasis hubungan karakterisitik tingkat disabilitas pasien pasca stroke terhadap status perkawinan juga menunjukkan hasil yang bermakna, yaitu ada hubungan yang signifikan 
antara status perkawianan pasien pasca stroke dengan tingkat disabilitas dengan nilai $p$ value $=0,000 \quad(p$-value $<0,05)$, hal ini sesuai dengan hasil penelitian tentang faktor resiko klien stroke oleh Ghani, et al (2016) dimana pada umumnya pasien pasca stroke sudah menikah dan hidup bersama. Dan juga usia pada pasien pasca stroke sebagian besar adalah usia tua yang sudah mempunyai pasangan hidup dan telah menikah. Hal ini juga sependapat dengan Sugiarti, (2010) yang mengemukakan bahwa status kawin penduduk usia tua akan mempengaruhi pola perilaku kehidupan yang dijalaninya, kebanyakan penduduk usia tua, tergantung kepada pasanganya. Pasien disabilitas pasca stroke yang telah menikah dapat mempertahankan aktifitas fisik dasarnya 1,25 kali dibanding dengan lanjut usia (lansia) yang tidak menikah/ sudah ditinggal pasangan. Lansia yang tidak menikah mempunyai resiko terjadi disabilitas 2 kali lebih besar dibandingkan dengan lansia yang menikah. Menikah mencengah terjadinya disabilitas baik bagi laki-laki, maupun wanita pada pasien lansia. Lansia yang menikah saling memberikan dukungan sosial satu sama lain yang dapat mencengah terjadinya disabilitas.

Peneliti juga melakukan analisis bivariate dengan uji cross sectional berdassarkan karakteristik disabilitas pasien pasca stroke terhadap tingkat depresi dari beberapa kareteristik yang dianalisis seperti jenis kelamin, status perkawinan tingkat pendidikan dan pekerjaan, menunjukkan hasil hubungan yang tidak bermakna dengan nilai $p$-value $>0,05$. Hasil analisis ini tidak sejalan dengan penelitian yang terdahulu yang dikemukan oleh Suwantara (2004), yang mengemukakan bahwa jenis kelamin juga memengang peranan penting dalam resiko terjadinya stroke, laki-laki memiliki resiko stroke lebih tinggi dari pada perempuan, namun karena rata-rata usia perempuan lebih panjang, maka pada suatu tingkat usia tertentu jumlah perempuan yang mengalami serangan stroke menjadi lebih banyak dari pada laki-laki, untuk perempuan angka kejadian depresi pasca stroke 10-25\% dan untuk laki-laki 5-12\%. Namun dari hasil penelitian yang dilakukan oleh Munir, et al (2016) sependapat dengan hasil analsisis dari penelitian ini yaitu tidak ada hubungan yang bermakna antara jenis kelamin dengan kejadian depresi pasaca stroke.

Hasil analisis hubungan karakteristik tingkat depresi terhadap kelompok umur menunjukkan hasil yang bermakna dengan nilai $p$-value $<$ dari 0.05 . yaitu $p$-value $=0,032$, hal ini sependapat dengan hasil penelitian Ratep $\mathrm{N}$ dan Putera (2014), mengemukan bahwa depresi menetap setelah 20 tahun pada $34 \%$ pasien pasca stroke. Semakin meningkat usia prevalensi depresi pasca stroke juga semakin meingkat, dimana usia $\geq 55$ tahun berisiko 5,8 kali menderita stroke dibandingkan kelompok usia 15-44 tahun. Suwantara (2004), juga mengemukakan, bahwa ada korelasi positf antara umur dengan depresi pasca stroke. Hal ini juga didukung dengan jumlah subjek penelitian yang dilakukan oleh peneliti dimana jumlah subjek peneliatan yang teritnggi adalah rentang usia antara 51-60 tahun sebanyak 66,7\%.

Hasil analisis hubungan tingkat disabilitas pasien pasca stroke terhadap depresi. pada penelitian ini menunjukkan bahwa ada hubungan yang bermakna antara tingkat disabilitas pasien pasca stroke terhadap depresi, yang ditunjukkan dengan nilai $p$-value $=0,018$ ( $p$-value $<0,05)$, yang artinya adalah semakin tinggi tingkat disabilitas pasien pasca stroke, semakin berat tingkat depresi yang dialami. Hal ini sejalan dengan apa yang dikemukan oleh Shinta et al (2013), bahwa pasien pasca stroke mengalami gangguan emosional, sulit mengontrol perasaan hingga menimbulkan depresi. Karena pasca terserang stroke membuat tingkat ketergantungan klien terhadap orang lain menjadi semakin meningkat, terutama aktivitas kehidupan sehari-hari seperti perawatan diri. Disabilitas juga merupakan kekurangan dalam kemampuan untuk melakukan kegiatan yang dianggap normal dilakukan oleh seseorang. Hasil analisi peneltian ini sesuai dengan yang dikemukan oleh Dharma K (2016) bahwa satu tahun menderita stroke $2,6 \%$ pasien mengalami disabilitas terutama dalam perawatan diri, dan setelah tiga tahun angka ini meningkat menjadi 36,3\%. Dampak lain yang dapat ditimbulkan adalah kelumpuhan, gangguan berkomunikasi hingga sampai mengalami depresi (Padila, 2013). Disabilitas yang dialami pasien pasca stroke dapat berupa kelumpuhan, kecacatan, gangguan berkomunikasi, gangguan emosi, nyeri, gangguan tidur dan disfagia. Sehingga jika disabilitasi pasien pasca stroke tidak dapat terpenuhi maka klien pasca stroke mengalami gangguan emosional, frustasi, kecemasan hingga depresi. Pengukuran disabilitas dilakukan berdasarkan kemampuan fungsional individu untuk melakukan aktivitas hidup sehari-hari secara mandiri Astuti (2009). Adapaun penilian tingkat disabilitas diukur berdasarkan penilaian kemampuan fungsional yang dalam hal ini mengunakan Indeks Barthel. Dalam penilaian ini ada 10 indikator dengan tiap penilaian fungsional diberikan skor mulai nilai 0 sampai 2, dengan penilan skor dikelompokkan menjadi 5 kategori yaitu, mandiri, 
ketergantungan ringan, ketergantungan sedang, ketergantungan berat dan ketergantuan total (Padila, 2013). Sedangkan item yang nilai adalah feeding, berpindah dari kursi roda ke tempat tidur dan sebaliknya. Melakukan personal toiler, melepas dan memakai kembali pakaian saat ditoilet. Mandi sendiri, kemampuan berjalan, mendorong kursi roda, nail dan turun tangga, berpakaian dan melepas pakaian. Mengontrol BAK dan mengontrol BAB (Darma, 2015).

Berdasarkan hasil penelian skoring ini dapat menimbulkan tingkat depresi pasien pasca stroke dimana depresi adalah suasana atau perasaan tertekan akibat penurunan kemampuan fungsional yang ditandai dengan perasaan atau hilangnya minat terhadap suatu hal atau kesenangan, prubahan selera makan atau berat badan turun, aktivitas psikomotor menurun, perasaan tidak berguna atau bersalah, kesulitan berpikir, konsentarasi dan membuat keputusan, atau bahkan dapat berupa serangan yang ditujukan pada diri sendiri atau perasaan marah (Azizah, 2011). Depresi dapat mengenai siapa saja yang memiliki penyakit serius seperti pasien pasca stroke berpotensi mengalami lebih tinggi

Depresi pasca stroke menyebabkan dampak negatif terhadap pulihnya aktivitas sehari-hari penderita stroke, penanganan yang efektif terhadap gejala depresi menunjukkan perbaikan yang nyata pada aktivitas sehari-sehari penderita.

\section{DAFTAR PUSTAKA}

American Heart Association/AHA. (2002). Risk factors. http://stroke.ahajournals. org/cgi/content/full/28/7/1507.

Ardi, Muhammad. (2011). Analisis hubungan ketidakmampuan fisik dan kognitif dengan keputusasaan pada pasien stroke di Makasar. [Tesis]. Depok: Universitas Indonesia).

Astuti, W. D., \& Budijanto, D. (2009). Tingkat Disabilitas Fisik Berdasarkan Penyakit Degeneratif yang Diderita Menurut Faktor Sosial Dan Demografi (Kajian Isu Publik dalam Formulasi Kebijakan Kesehatan). Buletin Penelitian Sistem Kesehatan, 12(4).

Avicenna. (2010). Perubahan Fisiologis Pasca Stroke. Jakarta: Rineka Cipta.

Aziziah. (2011). Keperawatan Jiwa (Aplikasi Praktek Klinik). Yogyakarta: Graha Ilmu.

Biantoro, Tohri, T., Juariah, L. (2015). Hubungan Karakteristik Individu Dengan Tingkat Depresi Pasca Stroke di Poliklinik Saraf

\section{SIMPULAN}

Tingkat depresi berdasarkan usia menunjukkan hasil yang bermakna semakin meningkat usia prevalensi depresi pasca stroke juga semakin meningkat, dimana usia $\geq 55$ tahun berisiko 5,8 kali menderita stroke dibandingkan kelompok usia 15-44 tahun. semakin tua penderita pasca stroke, kecenderungan mengalami depresi semakin besar, depresi, yang dialami terjadi sebagai dampak dari penuruan fungsional dan kecendrungan mangalami masalah kesehatan yang menetap dan berpontensi untuk menimbulkan ketidakmampuan untuk melakukan kegiatan sehari-hari. Berdasasarkan status perkawinan juga menunjukkan hasil yang bermakna, yaitu ada hubungan yang segnifikan antara status perkawianan pasien pasca stroke dengan tingkat disabilitas. Lansia yang menikah dapat mempertahankan aktifitas fisik dasar 1,25 kali dibanding dengan lansia yang tidak menikah. Lansia yang menikah saling memberikan dukungan sosial satu sama lain yang dapat mencengah terjadinya disabilitas. Semakin tinggi tingkat disabilitas pasien pasca stroke, semakin berat tingkat depresi pasien pasca Stroke. Untuk hal tersebut perlu adanya peningkatana edukasi kesehatan untuk mencangah disablitas dan depresi pada pasien pasca stroke.
RS Rajawali Bandung. Jurnal Stikes Ahmad Yani.

Dharma, K. (2015). Efektivitas intervensi model adaptasi pasca stoke (IMAPS) terhadap respon adaptasi dan kualitas hidup pasien pasca stroke. [Disertasi]. Depok: Universitas Indonesia).

Ghani L, Laurentia K M \& Delima. (2016). Faktor Risiko Dominan Penderita Stroke di Indonesia. Buletin Penelitian Kesehatan. 44, (1), 49-58.

Munir, B., Nasution, A. A., dan Purnamasari, Y. (2016). Determinan yang Mempengaruhi Depresi pada Pasien Post Stroke Infark di Rumah Sakit Saiful Anwar Malang. Neurology Journal. 2,(2), 59-62.

Padila. (2013). Keperawatan Gerontik. Yogyakarta: Nuha Medika.

Rahayu, S., Utomo, W., \& Utami, S. (2014). Hubungan Frekuensi Stroke Dengan Fungsi Kognitif Di RSUD Arifin Achmad. Jurnal Medica PSIK, 1(2), 1-10. 
Ratep N, Putera K. (2014). Depresi Pasca Stroke; Diagnosis Dan Tatalaksana. Cermin Dunia Kedokteran. 41,(2), 901-905.

Shinta, et al. (2013). Functional status and disability in stroke survivors or north India. Indian Journal of Physioterapy and occupational therapy. 7 (3). 59

Sugiarti. (2010). Determinan disabilitas pada lanjut usia di indonesia (analis data sekunder riset kesehatan dasar tahun 2007). [Tesis]. Depok: Universitas Indonesia.
Sugiyono. (2010). Metode penelitian kuantitataif kualitatif dan $R \& D$. Bandung: Alfabeta.

Suwantara. (2004). Depresi Pasca Stroke: Epidemiologi, Rehabilitasi dan Psikoterapi. Jurnal Kedokteran Trisakti, 23 (4): 29-38.

Tantular. (2015). Gangguan mood pada klien Stroke Ikhtisar Pustaka. Jurnal Ilmiah Kedokteran, 4 (1): 33-36.

Yayasan Stroke Indonesia (Yastroki). (2012). Angka Kejadian Stroke Meningkat Tajam. http://www.yastroki.or.id/ read.php? $i d=317$. 